\title{
ВОЛОНТЁРСКАЯ ДЕЯТЕЛЬНОСТЬ КАК ФАКТОР ФОРМИРОВАНИЯ ЛИЧНОСТИ МОЛОДОГО ЧЕЛОВЕКА
}

\author{
Н. А. Перинская, А. Д. Романюк \\ Московский гуманитарный университет
}

Аннотация: В статье рассматривается волонтёрская деятельность как социокультурный феномен современного общества; дается краткое описание опыта добровольческой деятельности в советский период российского общества; характеризуются основные признаки добровольчества, направления добровольческой деятельности и мотивы участия граждан в ней; на основе данных пилотажного исследования описаны основные личностные черты молодого волонтера и мотивы участия молодежи в волонтерской деятельности.

Ключевые слова: волонтёрская деятельность; волонтёр; фактор формирования личности; добровольчество

\section{VOLUNTEER ACTIVITY AS A FACTOR IN THE FORMATION OF A YOUNG PERSON'S PERSONALITY}

\author{
N. A. Perinskaya, A. D. Romanyuk \\ Moscow University for the Humanities
}

\begin{abstract}
The article describes volunteer activity as a sociocultural phenomenon of modern society; gives a brief description of the Soviet experience of volunteer activity; characterizes the main features of volunteerism, directions of volunteer activityand motives of people participating in it. On the basis of the data of a pilot research the authors describe the main personality traits of the young volunteer and the motives of youth participating in volunteer activities.
\end{abstract}

Keywords: volunteer activity, volunteer, factors of personality formation; volunteerism

Волонтёрская деятельность является одним из проявлений гражданского общества и относится к распространённой форме социальной активности людей. Она направлена на решение общественно важных проблем: помощь остро нуждающимся людям, не имеющим возможности помогать себе самим (пожилым, инвалидам, беспризорным, людям, пострадавшим от стихийным бедствий, социальных катаклизмов, катастроф). Волонтерская деятельность способствует развитию человека как личности. Участники волонтёрской деятельности проявляют милосердие, альтруизм, толерант- 
ность, справедливость. Волонтерство приобретает особую значимость в условиях нестабильности общества, когда появляются тысячи людей, нуждающиеся в помощи.

Термины «волонтер» и «доброволец» имеют практически единое значение. Однако, во втором случае уместным будет сделать акцент на нравственном аспекте слова. «Доброволец» - дословно означает добрую волю, работу, сделанную исключительно во благо и из гуманистических соображений, то есть труд без какого-либо денежного вознаграждения. Термин «волонтер» происходит от французского volontaire, что, в свою очередь, близко к латинскому слову voluntarius, означающему «добровольный».

Для понимания сущности добровольческого труда исследователи обращаются к категории свободы, отмечая, что характер такого труда и его специфика тесно связаны с освобождением труда от всех видов принуждения: социального, экономического, административно-правового.

К. Маркс определял добровольный труд как труд, свободный от угнетения и отчуждения. Он считал, что вместе с ростом производственных сил общества труд станет основной потребностью человека. Свободный труд труд противоположный таким историческим формам труда с внешним принуждением и отчуждением, как рабский, барщинный, наемный. Освобожденный труд способствует превращению человека в субъекта исторического процесса (Маркс, 1955).

По М. Веберу, появление социально свободного работника стало важнейшим условием формирования экономически свободного человека, личностная структура и поведение которого испытали определяющее влияние религиозной, в частности, протестантской этики (Вебер, 1990).

Добровольческий труд имеет свою историю в России с Древней Руси. Издревле к безвозмездной помощи и безвозмездному труду были причастны как представители простого люда, так и представители высших сословий. Люди трудились абсолютно бескорыстно в монастырях, в больницах, богодельнях, приютах для детей и сирот. На селе бескорыстную помощь оказывали при строительстве домов, в уходе за детьми, помощи одиноким людям, сиротам, осужденным. Как пишет Л. Е. Сикорская, в русских деревнях были распространены «помочи» - когда вся община помогала справляться с трудностями, непосильными одной семье. Помогали строить жилье, сеять и убирать огород и т. п. Семья заранее объявляла о «помочах», готовила угощение и все, что требовалось для работы (Сикорская, 2007). Мощный импульс безвозмездного труда наблюдался во время Русско-турецкой и Первой мировой войн. Сестры-милосердия добровольно отправлялись на фронт для оказания помощи раненым бойцам.

Одной из сфер востребованности добровольческого труда в России кон- 
ца XIX века обозначилось народное просвещение. Причиной этому была катастрофическая неграмотность. Ссылаясь на «Статистический ежегодник России», О. Г. Жукова отмечает, что, по данным переписи населения 1897 г., неграмотными были 78\% граждан страны, а грамотными считались уже те, кто утвердительно отвечал на вопрос: «Умеешь ли читать?» Вместе с тем, закон о всеобщем начальном образовании был отклонен в царской России в 1912 г. После Октябрьской революции 1917 г. Советская власть рассматривала ликвидацию неграмотности одной из важнейших задач модернизации страны. К участию в ликвидации безграмотности привлекаются многие «организации трудового населения», в том числе комсомол. Участие комсомола в ликвидации безграмотности стало массовым добровольным делом. Создание пунктов ликбеза, индивидуальная работа с неграмотными, сбор книг для деревенских библиотек и для малограмотных читателей, организация культурной жизни молодежи - все это выполнялось комсомольцами не в порядке трудовой повинности и не связывалось с оплатой их труда, а носило, как правило, общественный характер (Жукова, 2018: 86-90).

Добровольный труд получил массовое распространение в советском обществе. Формы и содержание такого труда имели широкий диапазон и были направлены на удовлетворение различных потребностей общества и государства в своём развитии. Принцип «Раньше думай о Родине, а потом о себе» воплощался в самоотверженных делах и поступках советской молодёжи. Всесоюзный Ленинский Коммунистический Союз молодёжи (ВЛКСМ) организовывал и возглавлял молодёжь на участие в комсомольских стройках, целинных и залежных земель, участие в субботниках и воскресниках, оказании помощи нуждающимся, заботе об инвалидах и пожилых людях; работе с детьми и т. д.

В годы Великой Отечественной войны наряду с призывом в вооруженные силы на основе всеобщей воинской обязанности военкоматы рассматривали миллионы заявлений добровольцев, среди которых большую часть составляли молодые люди. Так в июньские дни 1941 г. более 1000 воспитанников Московского университета (МГУ) ушли на фронт добровольцами (Макаревич, 2018: 118).

Для участия учащейся молодежи в общественном труде организовывалась учебно-производственные бригады, лесничества, лагеря труда и отдыха и др. Широко распространялось наставничество как передача опыта высококвалифицированных кадровых рабочих подрастающей рабочей смене.

В рамках деятельности Всесоюзной пионерской организации имени В. И. Ленина также проводилась большая работа по привлечению детей и подростков к добровольному труду. Одной из форм добровольчества стала 
тимуровская работа. Это как массовое патриотическое движение подростков, которое способствовало формированию гуманистических черт личности, а также стало эффективным социализационным механизмом для многих поколений советских людей. Известный детский писатель А. П. Гайдар в повести «Тимур и его команда», написанной в 1940 г., изложил увлекательную историю Тимура, вместе с друзьями помогавшего семьям красноармейцев. Поступок юного Тимура стал примером для подражания советских школьников. В годы Великой Отечественной войны общественно полезная работа определялась в следующих формах: забота о маленьких детях, уход за ранеными, оказание помощи эвакуированным детям, изготовление подарков фронтовикам, участие в сельскохозяйственных работах, сбор средств на подарки красногвардейцам, выступление с концертами, сбор металлолома и т. д. (Ковалева, 1996: 60-61).

Налаженный в советский период функционирования России механизм привлечения молодежи к участию в различных общественных делах в 1990-е гг. уже практически не действовал. Свернули свою деятельность детские и молодежные организации, выполнявшие воспитательную функцию. Преобразования, затронувшие все сферы общественной жизни, привели не только к положительным изменениям, но и к негативным последствиям.

В 1990-е годы общество востребовало новые формы общественной и добровольческой деятельности. Она была направлена на оказание помощи детским домам, лечебным учреждениям, поддержку учебно-научных программ. В это время начинают создаваться благотворительные учреждения и фонды. Российские исследователи связывают период конца XX - начала XXI в. с временем возрождения волонтёрской деятельности и началом становления волонтёрства как фактора, способствующего развитию и становлению гражданского общества.

Необходимость развития благотворительности как дополнительной формы социальной защиты продекларирована в статье 39 Конституции Российской Федерации (1993 г.). В 1995 г. был принят Федеральный закон «0 благотворительной деятельности и благотворительных организациях». Этот Закон впервые в нашей стране дал определение благотворительной деятельности. Указывалось, что благотворительная деятельность понимается как добровольная деятельность граждан и юридических лиц на бескорыстной (безвозмездной) основе или на льготных условиях по передаче гражданам или юридическим лицам имущества, в том числе денежных средств, по бескорыстному выполнению работ, предоставлению услуг, оказанию иной поддержки В этом Законе (статья 5) волонтеры (добровольцы) определяются как граждане, осуществляющие благотворительную деятельность в 
форме безвозмездного труда в интересах благополучателя, в том числе в интересах благотворительной организации.

Многие исследователи (Г. И. Бодренкова, Г. П. Бондаренкова, Л. А. Кудринская, Т. А. Локтионова и др.) отмечают значительное продвижение в развитии добровольчества в России за последние годы.

Определились основные направления добровольческой деятельности, к которым отнесено: поддержка социально незащищенных граждан, нуждающихся в защите и помощи, а также взаимопомощь и самопомощь; помощь в социальной адаптации людей, прошедших лечение от алкоголизма, наркомании и др. зависимости, а также бывших заключенных; охрана животных и окружающей среды; организация различных мероприятий с целью благотворительности; охрана, восстановление и сбережение объектов исторического и культурного наследия.

Среди признаков добровольчества, отличающих его от трудовой деятельности, социальной защиты и других видов деятельности выделяют добровольность; осознанность, когда человек на основе осознания своих мотивов, цели, средств участвует в добровольческой деятельности; инициативность; бескорыстие, личное непосредственное участие; социальная полезность.

К мотивам, по которым люди участвуют в добровольческой деятельности, относят желание помогать нуждающимся людям, доброту, неравнодушное отношение к происходящему вокруг, желание решить проблемы других людей и собственные проблемы (Азарова, 2018; Бондаренкова, 2013).

В волонтерской работе пересекаются индивидуальные и коллективные обоснования и мотивы. Предложенная М. Келемен, А. Мэнган, С. Моффат типология волонтерства является одним из подтверждений этого. Исследователи выделили следующие типы: альтруистическое волонтерство как акт щедрости, который совершается во благо другого; инструментальное волонтерство как способ извлечения личной выгоды вместе с вкладом в общее дело; активистское волонтерство, связанное с проявлением активной гражданской позиции, и добровольно-принудительное волонтерство (1) как ответ на призыв работодателя добровольно выполнить какую-нибудь работу и (2) как наказание в виде обязательных общественных работ (Kelemen, Mangan, Moffat, 2017).

В нашей стране получают распространение важные идеи Международной Ассоциации добровольческих усилий (IAVE), связанные с пониманием добровольчества как социального феномена. Остановимся на их основных положениях. В основе добровольчества просматриваются традиции и глубокие корни, исходящие из социальной природы людей, их желания отклик- 
нуться на нужды других и, объединив усилия, улучшать окружающую среду и собственную жизнь. Добровольчество возникает там, где в нем есть потребность. В любом обществе есть люди, которые нуждаются в помощи, как и люди, которые готовы помочь. Добровольческая деятельность выгодна как для людей получающих помощь, так и для тех, кто ее оказывает (Бондаренкова, 2013: 18-23).

В развитых западных странах волонтёрская деятельность рассматривается как способ поддержания и упрочнения принципов демократии, вовлечения граждан в процесс принятия решений. В этих странах волонтерству оказывается поддержка на государственном уровне, реализуются специальные программы по его развитию.

В России инициативной группой, занимающейся волонтёрской деятельностью, является молодёжь. Как известно, на молодого человека большое влияние оказывает социальная среда, в которой он выступает и как объект и субъект различных видов деятельности. Вхождение в молодежный возраст предполагает поступки, подтверждающие субъектность индивида в конкретных делах. Волонтёрство как общественно-полезная форма проявления социальной активности активизирует механизм социализации молодёжи.

Участие молодёжи в волонтёрской деятельности, как пишут А. Е. Чагин и М. В. Куимова, способствует как патриотическому воспитанию молодежи, так и формированию уважения к любому человеку, развитию готовности к сотрудничеству с другими людьми (Чагин, Куимова, 2015).

Как подтверждают исследования Л. Е. Сикорской (Сикорская, 2009), добровольческая социальная работа способствует формированию у молодого человека не только навыков, необходимых для профессионального роста, но и таких важных качеств, как трудолюбие, милосердие, доброжелательность, гуманное, толерантное отношение к людям.

За период со второй половины 1990-х годов по настоящее время в России накоплен опыт волонтёрской деятельности. На платформе «Добровольцы России» зафиксировано около 11 тысяч добровольческих организаций, 238 тысяч волонтёров. Большей частью 58\% являются молодые люди от 18 до 24 лет ${ }^{1}$.

Волонтёрская деятельность развивается. Этому способствуют разнообразные проекты и мероприятия, которые проводятся в различных регионах нашей страны. Особая активность наблюдалась в 2018 г., объявленном в России «Годом добровольцев».

\footnotetext{
${ }^{1}$ Статистика волонтерства в России: добровольцы России [Электронный ресурс] URL: http://want2help.ru/statistics/ (дата обращения: 15.05.2019).
} 
Научные труды Московского гуманитарного университета 2019 № 6

Московский гуманитарный университет также участвует в добровольческой деятельности. С 2015 года по инициативе проректора МосГУ Н. И. Ильинской здесь запущен масштабный экологический проект «Зелёный университет» ${ }^{1}$, главной целью которого является экологическое образование обучающихся. Каждый студент может стать частью этого проекта и записаться в ряды эко-волонтёров.

На базе Зелёного университета в МосГУ два раза в год проводится «Зелёная неделя», в программе которой: сбор макулатуры, мастер-классы по раздельному сбору мусора, Школа юного эколога. Студенты раздают полезные бананы у аппаратов с едой и напитками, проходят интересные лекции в форме дискуссий студентов с учеными-экологами на Eco Talks, где обсуждаются важные экологические проблемы и способы их решения. Много лет в МосГУ проводится акция «Батарейка, сдавайся!» с целью сбора батареек на переработку. Участники ярмарки «3D: Dари Dрузьям Dобро» обмениваясь старыми вещами, дают им новую жизнь. Университет присоединился к Всемирной акции «Час Земли».

Служба добрых дел, где обучающиеся МосГУ ведет волонтёрскую деятельность по различным направлениям: участие в акции «Дети России - детям Донбасса», ежегодное проведение Дней донора, участие в добровольческих фестивалях. Университет сотрудничает с Центром содействия семье и детям пос. Быково (Московская область) и Детской деревней SOS «Томилино» (Московская область), где студенты проводят мастер-классы для детей. Дети имеют возможность приехать в университет и поучаствовать в эко-недели, посмотреть спектакли и на зимний бал .

Выявление основных мотивов участия молодежи в волонтерской деятельности и определение личностных черт молодого волонтёра стало предметом нашего пилотажного социологического исследования. В опросе принял участие 61 респондент в возрасте 18-29 лет, занимающийся волонтерской деятельностью: 45 опрошенных (73,8\%) - женщины, 16 (26,2\%) мужчины.

В ходе опроса было выявлено, что основными мотивами волонтёрской деятельности молодежи является самореализация (70,5\%), помощь другим людям $(65,5 \%)$ и желание найти новые возможности и интересы $(60,6 \%)$.

Волонтёрская деятельность выступает для молодежи важной сферой социализации, обеспечивая продуктивное влияние на становление высоко-

${ }^{1}$ Зелёный университет (2019) [Электронный ресурс] // Московский гуманитарный университет. URL: https://www.mosgu.ru/main/green_university/title.php (дата обращения 19.05.2019). 
нравственных качеств личности молодого человека, побуждая его стать активным участником социокультурного процесса.

В условиях формирования гражданского общества становится крайне важным повышение гражданской ответственности и вовлеченности граждан в решение различных социальных проблем. Необходимо расширить привлечение молодежи, пожилых людей, а также граждан, представляющих возрастную группу экономически активного населения, к добровольческой деятельности. Добровольчество (волонтерство) представляет собой важный ресурс развития гражданского общества.

\section{СПИСОК ЛИТЕРАТУРЫ}

Азарова, Е. С. (2018) Психологические детерминанты и эффекты добровольческой деятельности : автореф. дис. ... канд. психол. наук. Хабаровск. 20 с.

Бондаренкова, Г. П. (2013) Системное развитие добровольчества в России: от теории к практике : учебно-методическое пособие. М.: АНО «СПО СОТИС». 320 с.

Вебер, М. (1990) Избранные произведения / сост., общ. ред. и послесл. Ю. Н. Давыдова; предисл. П. П. Гайденко. М.: Прогресс. 808 с.

Жукова, О. Г. (2018) Ликбез в советской России, или как молодежь стариков учила // Благодаря комсомолу...: сборник выступлений / под общ. ред. И. М. Ильинского, А. В. Костиной. Издательство ИКАР. С. 86-100.

Ковалёва, А. И. (1996) Социализация личности: норма и отклонение. М.: Институт молодёжи. 224 с.

Макаревич, Э. Ф. (2018) Великая победа и новые угрозы // Благодаря комсомолу...: сборник выступлений / под общ. ред. И. М. Ильинского, А. В. Костиной. М. : Издательство ИКАР. С 118-123.

Маркс К. (1955) Манифест Коммунистической партии // Маркс, К., Энгельс Ф. Сочинения. 2-е изд. М.: Государственное издательство политической литературы. Т. 4. С. 419-459.

Сикорская, Л. Е. (2007) Толерантность в представлениях молодых российских и немецких волонтеров социальной работы // Социологические исследования. № 9. С. 52-58.

Сикорская, Л. Е. (2009) Социализация молодежи в процессе добровольческой деятельности // Знание. Понимание. Умение. № 4. С. 138-145.

Чагин, А. Е., Куимова, М. В. (2015) О роли волонтерской деятельности в студенческой среде // Молодой ученый. № 10. С. 1327-1329.

Kelemen, M., Mangan, A., Moffat, S. (2017) More than a «little act of kindness»? Towards a typology of volunteering as unpaid work // Sociology. L. Feb 1. P. 1-18. Дата поступления: 12.12.2019 г. 
Перинская Наталья Алексеевна - кандидат социологических наук, доцент кафедры социологии Московского гуманитарного университета. Адрес: 111395, Россия, г. Москва, ул. Юности, д. 5. Тел.: +7 (499) 374-60-21. Эл. адрес: nperinskaya@gmail.com

Романюк Анастасия Данииловна - студентка факультета психологии, педагогики и социологии Московского гуманитарного университета. Адрес: 111395, Россия, г. Москва, ул. Юности, д.5. Тел: +7 (499) 374-75-95. Эл. адрес: romanyuk_97@bk.ru

Perinskaya Natalya Alekseyevna, Candidate of Sociology, Associate Professor, Department of Sociology, Moscow University for the Humanities. Postal address: 5, Yunosti St., Moscow, Russian Federation, 111395. Tel.: +7 (499) 374-60-21. E-mail: nperinskaya@gmail.com

Romanyuk Anastasiya Daniilovna, Student, Faculty of Psychology, Pedagogy and Sociology, Moscow University for the Humanities. Postal address: 5, Yunosti St., Moscow, Russian Federation, 111395. Tel.: +7 (499) 374-75-95. E-mail: romanyuk_97@bk.ru

\section{Для цитирования:}

Перинская Н. А., Романюк А. Д. Волонтёрская деятельность как фактор формирования личности молодого человека [Электронный ресурс] // Научные труды Московского гуманитарного университета. 2019. № 6. URL: http://journals.mosgu.ru/trudy/article/ view/1094 (дата обращения: дд.мм.гг.). DOI: 10.17805/trudy.2019.6.3 